\title{
TRAJANIC TREES: THE DACIAN FOREST ON TRAJAN'S COLUMN
}

\author{
by Andrew Fox ${ }^{1}$
}

Trajan's Column stands in the centre of Rome as a proud monument to Trajan's triumph over Dacia in the early second century. On its $29 \mathrm{~m}$ tall shaft, a helical frieze depicts the events of the two wars which won the province for the Roman Empire. There are 224 trees to be found throughout this relief, 222 of which are native to Dacia. These trees have traditionally been treated as scene dividers and background material to the column's action. This article, which begins by exploring the identification of the trees in previous scholarship, argues that they are in fact crucial to the column's narrative of industry and conquest. The discussion of identification is followed by an examination of the numerous tree-felling scenes on the column as a metaphor for conquest. The article closes with a detailed analysis of contrasting representations of the two leaders on the column, Trajan and Decebalus, one an urban emperor, the other a forest king. By directing attention towards the arboreal population of the column, this article argues that trees cannot be dismissed as mere background detail, but play an active and significant role in the communication of ideas about triumph, imperialism and the conquest of nature.

La colonna traiana si erge nel centro di Roma quale orgogliosa testimonianza del trionfo di Traiano sulla Dacia agli inizi del II sec. d.C. Un fregio elicoidale rappresenta sui suoi ventinove metri di altezza gli eventi delle due guerre che hanno portato alla conquista della regione e alla sua annessione all'impero romano. Sul rilievo possono essere rintracciati duecentoventiquattro alberi, duecentoventidue dei quali sono pertinenti a specie tipiche della Dacia. Dal punto di vista interpretativo gli alberi sono stati tradizionalmente letti come divisori di scene e allo stesso tempo come sfondi per le vicende narrate sulla colonna. Il presente articolo, che prende le mosse dall'analisi dell'identificazione condotta nella letteratura precedente, sostiene che gli alberi sono di cruciale importanza per la narrazione della conquista descritta nella Colonna Traiana. La discussione sull'identificazione sarà poi seguita da un esame delle numerose scene della colonna in cui gli alberi cadono, venendo queste raffigurazioni lette come metafore della conquista. L'articolo si concluderà poi con un'analisi dettagliata delle rappresentazioni contrastanti dei due leader rappresentati sulla colonna: Traiano e Decebalo, il primo imperatore, legato a una realtà urbana, e l'altro invece re di una realtà non urbana. Attraverso l'analisi rivolta alla popolazione arborea della colonna, questo articolo mira a sottolineare come gli alberi non possano essere considerati come semplici elementi di sfondo, ma che al contrario giocano un ruolo attivo $e$ significativo nella comunicazione delle idee concernenti il trionfo, l'imperialismo e la conquista della natura.

1 Research for this article, conducted in part at the British School at Rome while a student on the City of Rome course, was supported by the funding of the Midlands3Cities and Arts and Humanities Research Council UK Doctoral Training Partnership. I am grateful to the Editor, Alison Cooley, and the two anonymous PBSR readers for their helpful comments, and to Mark Bradley, Charles Watkins and William Leveritt for their advice and guidance. 


\section{INTRODUCTION}

Trajan's Column, erected in the emperor's forum complex by $\mathrm{AD} 113$ as a monument to his successful Dacian Wars, depicts the emperor in a foreign landscape, and is decorated with a helical relief that shows the events of these campaigns, and the land in which they were fought. ${ }^{2}$ Key to this landscape are the 224 trees on the column, each one of which is individually carved and stylized. These trees, and their exaggerated leaves, may have been painted, and the green of the leaves would have made them prominent features against the background of the frieze. ${ }^{3}$ It is via their leaves that the trees can be identified, and Christian Stoiculescu, a Romanian forest historian, catalogued them in his study (Stoiculescu, 1985), identifying 37 different leaf types on over 200 trees, which represent seven groups of species, including one large group of resinous trees. ${ }^{4}$ Stoiculescu's article is a little-known contribution to a long tradition of scholarship around the column which attempts to match the events depicted to known events of the Dacian Wars. It assessed the trees within the context of those that were native to Romania, where the wars took place.

Despite Stoiculescu's article being published earlier than Lepper and Frere's commentary (Lepper and Frere, 1988), and Coarelli's similar treatment of the column (Coarelli, 2000), the trees remain neglected or trivialized in the course of studying the relief, often dismissed simply as scene dividers, ${ }^{5}$ or, as in Leander-Touati's thesis on the Great Trajanic Frieze (Leander-Touati, 1987), as a curiosity within the background material. In fact, Stoiculescu's article has only been cited a handful of times, and engagement with its content has been

2 This is in contrast to the Column of Marcus Aurelius, which focuses more on the individuals, with significantly less concern to depict the world in which the war was fought, perhaps a symptom of the change in style between the two periods.

3 Whether or not the column was painted is a question which was first raised in the early 1800s, and although recent analysis has found no evidence of surviving paint on the column's relief (Conti, 2000), there have been more recent colour reconstructions, following renewed interest in polychromy in ancient sculpture (Pogorzelski, 2012).

4 Throughout this article, Stoiculescu's categorizations will be referred to, taken from the database at the close of his article (Stoiculescu, 1985: 96-8). These individual identifications will not be given a page reference at every point, for the sake of avoiding repetitive citations.

5 This has been an extensively covered aspect of scholarship since serious study of it began in the nineteenth century, leading a reviewer of a new study of the column to identify the scene-dividing trees as 'well-known' (Coulston, 1990a: 296). Cichorius identified several scenes which he presented as the beginning and end of scenes in his edition of the frieze. He planned to expand on his definition of scene dividers in a second study, but this never materialized (Cichorius, 1896: 5). Lehmann-Hartleben used this absence to present a counter-argument, focusing on the image of the scene as opposed to the elements which delimit images, although his divisions remained largely the same as Cichorius' (Lehmann-Hartleben, 1926: 122). This disagreement was picked up on by Gauer, who reduced the number of scenes on the column to 100 , removing a number of Cichorius' divisions (Gauer, 1977). Malissard also identified a number of trees as framing scenes (Malissard, 1982), and Leander-Touati extended the use of trees framing scenes to the Great Trajanic Frieze (Leander-Touati, 1987: 32-3). 
limited. ${ }^{6}$ While trees clearly can and do operate as scene dividers in certain parts of the column, this is not the only use of arboreal features on the frieze. The importance of the trees can be inferred from the intricacy of their carving, which is no less detailed than that of the faces, costumes and urban architecture on the column. ${ }^{7}$ In their considerations of the carving of imperial reliefs, Wootton and Russell arrived at two key conclusions regarding the trees. First, they appear to have been carved by at least two different sculptors (Wootton and Russell, 2013: 16), and second, they were rendered with an extraordinary level of detail regardless of the height at which they were carved (Wootton et al. 2013: PR205_1_05_20 http://artofmaking.ac.uk/explore/sources/519/). ${ }^{8}$ These two observations, when considered alongside the variety of trees identified by Stoiculescu and the sculptural precision that was applied to them, invite the viewer to consider the broader role and significance of trees on this iconic early imperial monument.

Beyond the commonly accepted usage of the trees as a scene divider, there are two other major purposes of the Dacian forest on Trajan's Column, and it is these which will be addressed in this article, after a brief survey of Stoiculescu's earlier study and identifications. First, I will explore the role of trees in the column's depiction of the Roman army in a foreign landscape, focusing on their appearances in deforestation or tree-felling scenes, which usually lead into construction scenes, as in the road construction of scene XCII. ${ }^{9}$ These trees are almost always felled by Roman soldiers, ${ }^{10}$ although the extent of deforestation is only partially represented by the column's frieze, as Thill (2010) has shown, and should perhaps be understood synecdochally. Thill identified that the majority of Dacian structures on the column's relief ( 55.7 per cent) are made entirely of wood, while only 16 per cent of the Roman structures on the column are exclusively wooden. This conflict in the evidence presented, that Roman forces perform most of the tree-felling on the column, while their constructions are rarely made of wood, will be addressed in this article,

\footnotetext{
6 The most use that is made of this study is in two reviews, one by Coulston, of three commentaries on Trajan's Column, and another by Houston, on the treatment of technology in the ancient world. Coulston, 1990a: 296, commented on Settis's use of trees as scene dividers on the frieze, while Houston, 1989: 72, was surprised by the lack of reference to the column in Meiggs's Trees and Timber in the Ancient Mediterranean World (Meiggs, 1982), in light of Stoiculescu's study.

7 For recent discussions of these individualized and highly stylized depictions on the column, see on costumes: Goldman, 1994; Coulston, 2003; urban architecture: Coulston, 1990b, and more recently Thill, 2010.

8 The two techniques of carving trees, one flat and lifeless, the second vibrant and vivacious, indicate to Wootton and Russell that there were at least two sculptors of the trees on the column (Wootton and Russell, 2013).

9 The depiction of this road has been analysed by Rossi, 1968, who argued that depictions of military engineering, such as that of the road, were the easiest way to portray the triumphal concept.

10 There are three instances of Dacian tree-felling on the column, at the close of the First Dacian War, scene LXVI. This is compared to 45 trees felled by Romans, and a significant amount of additional timber carried by Roman soldiers.
} 
concentrating on an interpretation of the scenes that is allegorical rather than literal. The article will then move to an examination of the context in which the opposing leaders - the Dacian king, Decebalus, and the Roman emperor, Trajan - appear on the relief. Through a consideration of these two figures, and the figures around them, this article will demonstrate that trees functioned as a narrative tool on the column, and will attempt to provide some suggestions as to why such a wide variety of trees can be found throughout the column's relief. Through these aspects of arboreal representation on the frieze, I will explore the nature of warfare that is represented on the column, and the cultural and narrative significance of the 224 trees depicted.

\section{IDENTIFICATION}

The trees have undergone rigorous assessment at the hands of Stoiculescu (1985), who matched the leaves from the frieze to those on two groups of secular trees (i.e. groups of trees which have remained a consistent feature of the region) in the Southern Carpathians of Romania. The main division drawn by Stoiculescu is between resinous and deciduous trees. The resinous trees are typically evergreen and identifiable by their straight trunks, growing from a single point. These trunks are almost invariably more than half the height of the tree (some allowance must be made for the two trees in scene III, given that they are at a significant distance from the scene's action), and are topped with a narrow excurrent crown, which typically only has a few branches, often with the tree's needles directly attached to the trunk. It is through these needles that Stoiculescu (1985: 85) divided the resinous trees into subspecies.

The trunks of the deciduous trees are twisted, and 'full of imperfections', which are particularly noticeable given that they usually lack branches on the trunk's bottom half. Further, these trunks are fluted, pitted and with visible loose knots, an indication of the dedication of the sculptors to projecting an appearance of reality. The expectation would be for branching, particularly on deciduous trees, to start earlier on the trunk, as opposed to the column's depictions, in which the spreading branches of the deciduous trees are restricted to the top of the relief. The knots on the trunks suggest that the lower branches expected on these trees have been removed. The crown of these deciduous trees was described by Stoiculescu (1985: 85) as either umbelliform (with laterally spreading branches) or obovate (with branches spreading from a central point).

Following his division into resinous and deciduous trees, Stoiculescu further identified seven distinct groups of subspecies, which are further split into a total of 37 different leaf variations (Fig. 1). Stoiculescu contended that the first subspecies group, of resinous trees, is impossible to diagnose with more precision. Despite this, the clear differentiation between the types within group A indicates the importance of variety and specificity within the resinous tree types, as well as potential authorial intent to differentiate between the species. 


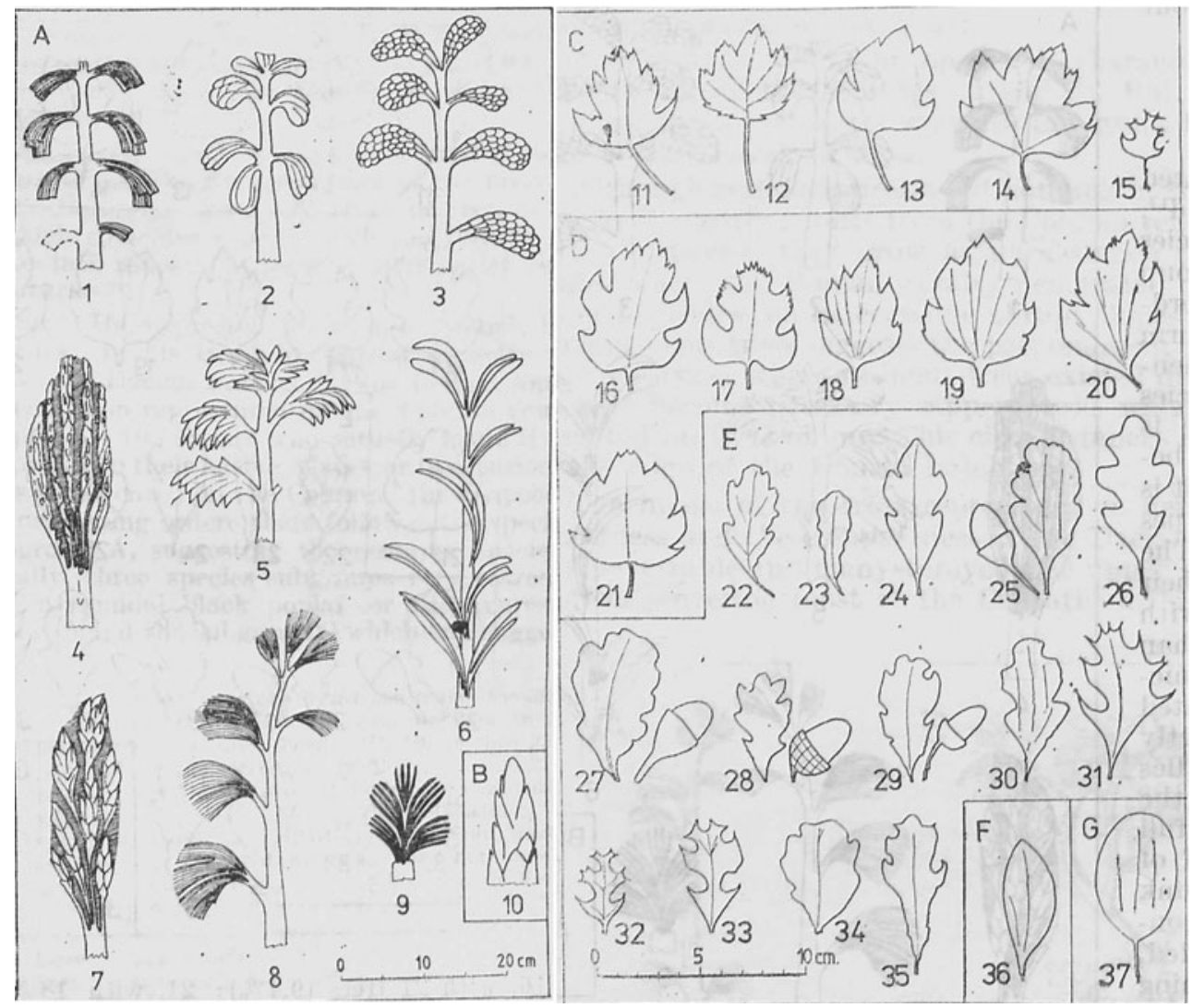

Fig. 1. Leaf types on Trajan's Column, as identified by Stoiculescu (1985: figs 4 and 5). Reprinted by permission of Vasile Pârvan Institute of Archaeology, Bucharest. Stoiculescu describes the resinous leaf types (A and B) as follows: 'Resinous species types included in the A and B species subgroup according to the crown and needle forms. Columnary crown: type 1 - long and pendent needles; type 2 - revolute, semilanceolate needles; type 3 - short and scaly needles; type 5 - needles grouped in pendent fascicles; type 6 - slightly revolute, lanceolate, big needles; type 7 scaly and oblong needles; Pyramidal crown: type 10 (suggesting a primitive form of the actual pyramidal black poplar - Populus nigra L. cv. Italica - or the cypress Cupressus sempervirens L.) Semipyramidal crown: type 8 - needles grouped in short fascicles; Rhomboidal crown: type 4 - long and scaly needles, catenary disposed; Ovate crown: type 9 - erect, fanned, exclusively disposed at the tree top.' The leaf types of the deciduous trees $(\mathrm{C}-\mathrm{G})$ are listed thus: 'Foliaceous species types divided in five subgroups according to their form of leaves: $\mathrm{C}-$ pentapalmary lobate leaves (suggesting Acer genus), D - broadly ovate leaves, with 3-5 triangular lobes slowly decreasing to the top (suggesting Sorbus torminalis L.), E unregularly obovate and pennate lobate leaves (suggesting Quercus genus), F oblong leaves (suggesting Prunus genus), G - elliptic leaves (suggesting Fagus genus).'

Depictions of the beech, or fagus, are both rare and unusual, since the tree only appears in one form (Type G.37), and is only seen once on the column. The motivation for this, Stoiculescu argued, is that 'the beech was much too common' (1985: 89), and he went on to suggest that Trajan aimed instead to 
impress his audience with a conquest over an exotic and foreign land, populated with strange-leafed trees. While the level of control that Trajan exerted over the frieze's arboreal contents is unclear, it is widely accepted that his account of the wars, the non-extant Dacica, would have had some influence on the overall intentions of the column, if not its individual components.

As to how accurate this strange-leafed land was to the contemporary Dacian landscape, Stoiculescu argued that the trees were reasonably representative of the forest at the time. He excluded from this assertion both the absent beech, and the two non-Dacian trees (Type B.10) found on the Roman side of the Danube at the start of the relief, in a walled city. Stoiculescu's assertion is part of a broader narrative, attempting to fit the trees into an argument that the relief is an accurate depiction of Dacia itself. Meiggs concurred with this assessment, in a brief observation regarding Trajan's Column. Focusing on the deforestation scenes, Meiggs (1982: 186-7) commented that the majority of the trees felled were oak, and that 'this was not because they were more decorative; oak was the dominant species in these central European forests'. This comment appears to have been picked up in subsequent studies, and Lepper and Frere identified trees as oaks, firs or poplars, dependent on whether they are resinous or deciduous. ${ }^{11}$ This association of the oak has also been influenced by a remark made by Pliny the Elder, in Naturalis Historia (3.147), who identified the neighbouring region of Pannonia as 'acorn-bearing'. ${ }^{12}$ As a result, the impressive variety of foliage which Stoiculescu identified on the column has often been overlooked, and presented as a homogeneous block of trees, instead of the impressive range on offer.

A key difficulty in the depiction of such a wide variety of trees on the column lies in both their visibility and their recognizability. Visibility has been an issue

11 Lepper and Frere, 1988: 53, identified the two non-Dacian trees of scene III as Lombardy poplars, or populus nigra, while all others were identified as fir or oak. Lepper and Frere, 1988: 64 - 'the trees are certainly oaks', identified by Stoiculescu as three sycamores (Type C.12) and one oak (Type E.24); 66 - 'fairly typical oak tree divider' (Type D.16 - service tree); 69 'mixed forest of oaks and conifers' (three Type A.3 - resinous trees, two Type D.19 - service trees); 80 - 'the sharp conifer divider' (Type A.5 - resinous trees); 85 - 'an oak-tree divider' (Type E.30 - oak); 91 - 'poplars as dividers and oaks for timber' (general comment referring to scenes 46-73, which contain 73 trees, of four subspecies, and 25 different types); 105 - 'the oak-woods' (two Type E.31 - oaks, one Type E.23 - oak, and one Type C.15 - sycamore); 108 - 'a double tree division (poplars or conifers?...)' (Type A.6 - resinous); 109 - 'the tall conifer' (Type A.5 - resinous); 111 - 'the tall conifer' (Type A.9 - resinous); 121 — 'a poplartree' (Type A. 4 - resinous).

12 This association is in some conflict with the use of the oak on the Arch of Trajan at Beneventum to represent the German territories (Rotili, 1972), and Schama's extensive analysis of Germany's oak fetishism (Schama, 1995: 75-134). Further, Pliny distances himself from tying the tree exclusively to the province (Plin. HN 16.17 - cum robur quercumque vulgo nasci videamus). However, Pliny was being specific in this example, specifying the robur and quercus, while neglecting the aesculus and other varieties of the oak. Additionally, the profligacy of the oak would not prevent it from being strongly associated with more than one region.

The abbreviations system used herein follows the Oxford Classical Dictionary, ed. S. Hornblower, A. Spawforth and E. Eidinow (Oxford University Press, fourth edition, 2012 and online). 
with the column's frieze since study of it first began, with numerous solutions proposed, from the vertical axis viewing first suggested by Lehmann-Hartleben (1926) and later by Gauer (1977), to the neighbouring viewing platforms put forward by Coarelli (2000). ${ }^{13}$ With regard to the trees, however, there remains a difficulty. In spite of the deliberately exaggerated leaves, clearly intended for the differentiation and identification of the tree species, there is an assumption that a Roman observer of the column would be familiar enough with trees to be able to identify them, and to place them as Dacian trees.

The first difficulty with this assumption is that the trees depicted on the column's frieze are not exclusively Dacian. As already briefly mentioned, the oak, one of the more common species on the frieze, was found across Europe at this time, and the same can be said of the other two dominant foliaceous trees: the service tree (a type of wide-ranging sorbus genus, which includes mountain ash/rowan in its variations) and the sycamore. Similarly, Romans would have been familiar with a variety of resinous trees, evidenced through a poetic record stretching as far back as Ennius' Annals (Sk. 6.177); and the agricultural handbooks of the mid- to late Republic and early Principate, written by Cato the Elder, Varro and Columella, discuss a large number of resinous trees. While these books would only have been read by a few individuals, the implication of their coverage is that there would have been some degree of familiarity with the trees in Rome and its surrounding territories among the wider community without knowledge of specific species. To what extent it matters, however, that these trees may already have been familiar by sight to the Roman people will be dealt with shortly, in the context of treefelling on the column and the triumphal procession.

Through identifying the different varieties of trees, a study of the column reveals an almost complete depiction of the (expected) Dacian landscape of the time. The absence of the beech is particularly important, since it reveals that the sculptors were selective over what trees they carved, and the range of leaf types shows a concern for individualized depictions, as in the human figures on the relief. Clearly, they were carved with this much care, even in the unenthusiastic style of the second sculptor (as highlighted by Wootton and Russell, 2013), for a purpose, and that purpose may become clear as we explore the different functions of the column's trees.

\section{DEFORESTATION}

Forty-eight trees appear in deforestation scenes on the column, making it one of the most common contexts in which trees appear on the relief, and these scenes are found from the column's opening. The first example of deforestation is in

13 Brilliant, 1984: 90-4, strongly criticized the design of the column, for the circular motion required of any viewer intending to view the relief as a continuous narrative, and for the difficulty that the viewer has in understanding the uppermost scenes on the relief. 


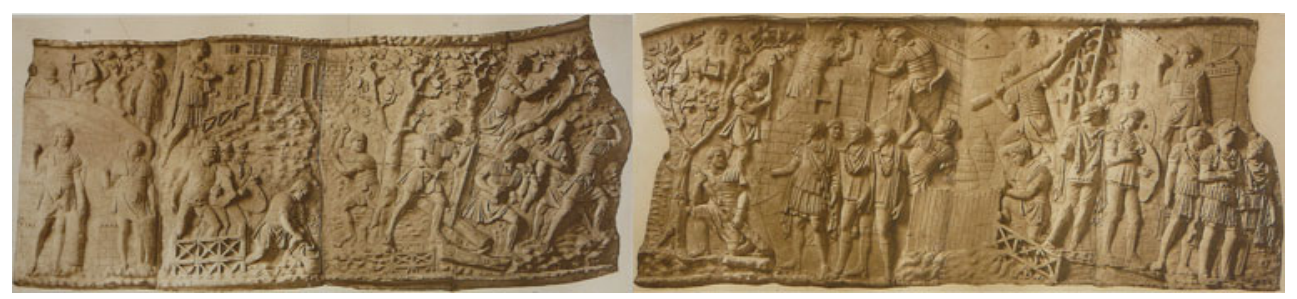

Fig. 2. Scenes XV-XVI. Deforestation can be seen in scene XV, on the left, watched by Trajan from scene XVI on the right. The trees are, in order, three times C.12, and one E.24. Source: Cichorius, 1896: plates XIII and XIV.

scene XV (Fig. 2), and the activity continues up to the final tree-felling scene in CXXXVII. The usual content of the deforestation scenes is exceptionally revealing: beyond three instances of Dacian tree-felling, all within the same scene, Roman soldiers are felling Dacian trees, in line with the general theme of industry on the column's relief. Davies (1997: 63) commented that the column 'downplay[s] the gruesome realities of war' and instead depicts more peaceful themes, of travel, construction, adlocutio, submissio and sacrifice. ${ }^{14}$ Coulston (2003: 403) has added to Davies's earlier comments, noting that the battles are commonly fought by 'non-citizen auxiliary troops', while the Roman citizen troops are lauded for their 'building construction, field-craft and siege warfare'. ${ }^{15}$ The absence of warfare and the prominence of construction scenes is, for Davies (1997: 63), part of an effort to portray a mechanized Roman army, in complete control of both its surroundings and the war. In this reading of the column, the tree-felling scenes are key, and when this is put in the context of the Romans' relationship with the environment in times of war, a fresh understanding of the usage of trees on Trajan's Column begins to emerge. However, challenges arise when tree-felling on the column is considered within the broader tradition of tree-felling in Greek and Roman myth and history, and there has typically been an assumption made by modern scholars that any deforestation is a sacrilegious act. ${ }^{16}$

Recently, Hunt (2016) has readdressed this assumption, and has explored the possibilities of sacrality in trees beyond a wholesale attribution. ${ }^{17}$ This leads to a

14 The lack of battle scenes has allowed Ferris, 2000: 61-85, to identify the warfare shown on the column as a 'sanitised' version, thus allaying the Roman population's fear of the army, while the possible association of the Dacian with the forest and the Roman with construction presents a clash between nature and culture.

15 Elsewhere, Coulston, 1990b: 49, suggested an association between the 'differing degrees of architectural verisimilitude' and the propagandistic nature of the column.

16 This assumption is found in Boetticher, 1856: 195. It is continued in modern discussions of the ancient relationship with the tree, from Thomas, 1988: 263, to Dyson, 2001: 146-7, and beyond, to Hughes, 2014: 185. The primary issue for several discussions of the felling of trees is one of inviolability, and this is briefly summarized by Dowden, 2000: 108-9.

17 Hunt tackled the issue of constrictive definitions of sacer, such as the legalistic one, in the introduction to her book (Hunt, 2016: 1-28), 'Rooting in: why give time to sacred trees?', and 
challenge in identifying which trees are sacred, which prompted Thomas (1988: 263) to conclude earlier that 'any tree felling [is] potentially hazardous', and the consequences for such a felling are usually severe. ${ }^{18}$ The felling of the trees on the column operates alongside this rich literary tradition of negative deforestation, but also engages with a cultural tradition, with its roots in the late Republic and the conquest of foreign nations.

As should be expected with the relief, all the felled trees are in Dacian territory, and many felled trees are oak, a tree associated with Dacia by modern scholars, as noted above. In scene XV, the trees were identified by Lepper and Frere (1988: 64) as being exclusively oaks, although Stoiculescu's analysis of the foliage has proven otherwise. Regardless of their error in this particular scene, oaks are prominent on the column, and the argument of Lepper and Frere that certain trees can be considered characteristic of Dacia is useful. While the trees in scene XV are not exclusively oak, they are all trees which Stoiculescu identified as being typical of a Romanian forest, and he added (1985: 84) that 'the priority cutting of the deciduous trees suggests the preponderant waging of the two Dacian Wars just in this vegetation-zone type, where resinous trees existed only sporadically'. These authors direct us to the conclusion that the forest depicted on the column is both authentically and symbolically Dacian, being composed of trees that were both theoretically common to the area, and traditionally associated with it. ${ }^{19}$

The need to display trees symbolically associated with the conquered Dacian territory is comparable to the triumphal importation of trees, a practice already discussed in some detail by Östenberg (2009: 184-8). The imported trees, Östenberg argued, stood for the race to which they originally belonged, and the land that they originated from. She took her lead from two brief accounts found in Naturalis Historia, the first of which indicates the importation of ebony by Pompey (12.20), and the second relating the display of the balsam by Vespasian and Titus (12.111-12). There is a clear differentiation between trees and timber, indicated by Pliny's specific use of arbores when referring to the practice in general, and the presence of the timber in Rome previously (12.17-18). Additionally, Östenberg noted (2009: 188) the usage of the verb

addressed the issue of felling trees in her fourth chapter, 'Arboriculture and arboreal deaths: rethinking sacrality again' (Hunt, 2016: 121-72). In the fourth chapter, Hunt acknowledged that an unviolated wood, whether or not it was dedicated, had the ability to provoke a religious reaction (Hunt, 2016: 125, citing Ov. Met 3.28; Fast. 2.435; Stat. Theb. 4.420; Luc. De Bello Civile 3.399).

18 In myth and history, the punishment is traditionally dismemberment or decapitation, from Halirrhothius' axe rebounding from Athens's sacred olive tree and killing him (Scholion in Aristophanes, Nubes 1005; Serv. G. 1.18), to Turullius' execution by Augustus (Cass. Dio 51.8; Val. Max. 1.1.19). In both of these examples, the trees felled were sacred ones, either to Athena (as in the case of the olive) or to Asclepius (as in Turullius' delayed execution on Cos).

19 Here, the absence of the fagus proves challenging for Stoiculescu, who appears to have expected it to be far more common on the relief than it actually is, given the tree's prominence throughout. As was discussed above, this can be excused by the need to display trees which would have been considered exotic or particularly Dacian, as opposed to the more common fagus. 
ducere (to lead) in the context of displaying the trees in the triumph, a verb only used for the living spoils (e.g. prisoners and animals). Östenberg pointed to the balsam in particular, which pays tribute to Rome alongside its gens (12.112). In applying the attitudes which led to this practice to the trees on Trajan's Column, and to trees in conflict more broadly, a new tradition emerges: war on the landscape, which is expressed through the prominent tree-felling scenes. ${ }^{20}$

These scenes show the Roman forces waging war on the land of Dacia itself. Unlike the negative deforestation tradition, the deforestation of the trees on the relief has no adverse consequences for the Romans, and the focus is on industry, a focus clearly expressed in the first tree-felling scene on the column, scene XV. This scene runs almost seamlessly into scene XVI. Cichorius' division between the two was contested by Lepper and Frere (1988: 64-5), who identified the trunk of the oak tree at the close of XV as a 'stage-prop rather than a divider'. The continuity between the two scenes, highlighted by the figure of Trajan, who is looking back at XV from XVI, implies that the timber felled in the earlier scene was used to construct the Roman fort of XVI. In contrast to the tradition of negative deforestation, this is not presented as a violation of a potentially sacred tree. Rather, the industry of the Romans, ratified by the emperor's approving gaze, is displayed in a positive light. The Roman soldiers are seen taking control of the foreign landscape, moulding it to their purpose, and in doing so urbanize their rural surroundings, in contrast to their Dacian enemies. ${ }^{21}$

War on landscape is a common theme in descriptions of the Dacian Wars, particularly in the accounts of Pliny the Younger. Control of the landscape is a key component of Trajan's portrayal, in contrast to Decebalus in the Panegyricus, Pliny's only surviving speech, written and delivered prior to Trajan's first Dacian War. In this panegyric, written in the expected hyperbolic fashion, ${ }^{22}$ Pliny described the land of the 'barbarian king', and its betrayal of the native ruler. The river and the mountains prefer to part for Trajan to advance, before turning and fighting for the emperor (Plin. Pan. 16.5). Here, a

20 This tradition is replicated in Trajan's mastery of the sea, expressed in Pliny the Younger's Panegyricus, and analysed by Manolaraki, 2008.

21 The three trees felled by Dacians in scene LXVI further this idea of the Roman army subjugating the Dacian landscape throughout the column's relief. The scene in which the Dacians are maintaining their control of the landscape is towards the end of the First Dacian War, and the conquest of the country is not yet complete.

22 The hyperbole of the Panegyricus has historically provoked a dismissive response, found throughout readings of Pliny's lengthy speech. Syme commented that, as a speech, it has done 'no good to the reputation of the author or the taste of the age' (Syme, 1958: 114), while Radice called it 'indispensable yet unreadable', adding that 'some of its topics are laboured to the point of obscurity or hidden behind a façade of elaborate rhetoric' (Radice, 1968: 169). Recently, the Panegyricus has gained more status as a valuable source for senatorial imperial oratory, and its themes have been explored in an edited volume (Roche, 2011). 
good emperor is seen in complete mastery of the forces of nature. Hutchinson compared this (2011: 128, citing Plin. Pan. 50.1) to the negative portrayal of Domitian later in the speech. He added that Domitian's mastery of nature is artificial and incomplete compared with the willing submission of the landscape to Trajan. Moving genre, to Pliny the Younger's letter to Cannius Rufus, the theme continues. Here, Pliny related Trajan's command of the landscape, his creation of new rivers, and the subsequent bridging of these rivers, an echo of the bridging of the Danube at the base of the column's frieze (Plin. Ep. 8.4). ${ }^{23}$

It can and should be assumed that Trajan invoked the tradition of arboreal triumphal imports in his triumphs over Dacia, and that he displayed the trees of the land alongside the river deities and other natural features, particularly in the absence of a foreign ruler. It is therefore not unlikely that the emperor followed similar precedent and incorporated these trees, Dacian by their association with the triumph, into his forum complex, in the pits excavated by Packer in 1982, which form double colonnades in the Area Fori, identical to the known avenues of plane trees in the Porticus Pompeiana (Packer, Sarring and Sheldon, 1983; Packer, 1997: 418-19). ${ }^{24}$

While tree-felling is prominent on the column's relief, it is not portrayed within the expected negative deforestation tradition. Instead, it taps into a broader

23 Control of the landscape was critical to Roman conquest, and within Roman war. The oldest crown of the Republic, according to Plin. HN 22.8, was composed of grass of a conquered site, and indicated the absolute surrender of the territory and the peoples within it. Fabrizi, 2016: 286, pointed to the emblematic significance in the Second Punic War of Scipio's sea crossing to Africa throughout her chapter, and also suggested the importance of nature in warfare when discussing the role of fog and dust in the battles of Trasimene and Cannae.

24 It is, unfortunately, impossible to distinguish which trees were planted in the planting pits in the Area Fori, although Packer theorized that they were ilex trees, in line with the architecture of the area, and discounting the plane (platanus), which was common in other avenues of trees at the time but was too large for these pits. However, it is possible that the pits, which are represented on the Marble Plan, housed the trees that were associated with the territories of Germany and Dacia, Trajan's two primary conquests, and which are consequently represented on triumphal Trajanic architecture. That trees were incorporated into Rome's urban plan is a commonly accepted fact, as is their presence on the Marble Plan (Lloyd, 1982: 92, citing Carettoni, 1960: 202). It is possible that the trees from the Dacian triumph were incorporated in a similar manner to the plane trees (regarded as 'quintessentially Asian' - Totelin, 2012: 134) in Pompey's porticus, in order to advertise his political power (Stackelberg, 2009: 76). The remains of these trees were discovered under the Teatro Argentina as a result of soundings, and could have been represented on the Marble Plan (Coarelli, 2007: 285). While there is no attestation in ancient sources that the theatre complex was manubial, it is often treated as such, and Russell argued that some of the artworks in the complex 'must ... have been seized as [Pompey] dismantled Mithridates' enormous treasuries', and that 'the live trees Pliny reports were carried in the triumph must be the same as those which later graced the portico and gardens' (Russell, 2016: 163; see also Kuttner, 1999: 345, 356). While this is impossible - Pliny reports that the trees were ebony trees, which do not grow in the temperate climate of Rome (Plin. HN 12.111, cf. Verg. G. 2.116-17) — Pompey may have substituted the Indian ebony with the equally Asian plane. 
cultural tradition that incorporates the importation of the trees in the triumphal procession, the urban habitat of the Romans as opposed to the rural character of the Dacians, and the industry required. I have characterized this earlier as a war on the landscape - an attitude which acknowledges the Roman war on the country, represented here by the trees, and by the similarly tamed Danube - as well as a war on the people. As a result, the victory depicted on the column is not only a victory over the Dacians, but also over Dacia itself, which has now come under Roman control.

\section{TRAJAN AND DECEBALUS}

The preceding section showed how the deforestation scenes on the column could be characterized as a part of war on the landscape. The use of trees as a narrative device can also be found in the depictions of the two leaders, who appear among trees several times on the column: Decebalus is shown in a forest setting four times, and Trajan three times. On the face of it, these numbers seem unremarkable until compared with the total number of appearances of each leader: Decebalus is depicted six times on the column, compared with Trajan's 57-60 appearances. In other words, the Dacian king is over ten times more likely to be found in a forest setting than his Roman counterpart. This might be expected, given the conflict between culture and nature inferred by Ferris (2000: 61-85), which he extended to being between Roman and Dacian, and then between barbarism and civilization. The portraits of Trajan on the column, which may have been coloured purple and thus be extremely visible to the viewer, are in line with his general portraiture. Tuck (2015: 226) has argued that the expected Augustan qualities of virtus, clementia and pietas are visible throughout this portraiture, as opposed to being restricted to depictions on this monument. The common forest setting of the Dacian king is often in direct contrast to the expected virtues from the clipeus virtutis, as will become apparent.

Decebalus' appearances on the relief are framed by two in which the trees have a central role in the scene's events. His first appearance, in scene XXIV, is one of surveillance, as he watches from the back as the armies clash in the opening battle of the relief, likely the second Battle of Tapae, which was won by the Roman forces (Fig. 3). The trees that dominated the previous scene, one of Roman deforestation, reappear at the close of this one, as the Dacian troops attack from the forest that shelters their watching king. He hides underneath a resinous tree and behind an unusually small deciduous tree with broad palmate leaves, identified by Stoiculescu as a service tree, and is the final figure in the top half of the scene. This first appearance of Decebalus is clearly not a positive one, and attention is drawn to him by the projected line of the thunderbolt wielded by Jupiter Tonans, seen here to the upper left of Decebalus, slightly to the right of the centre of the battle. This is simply conjecture, since the thunderbolt itself is missing, but by extending Jupiter's line of sight, and 


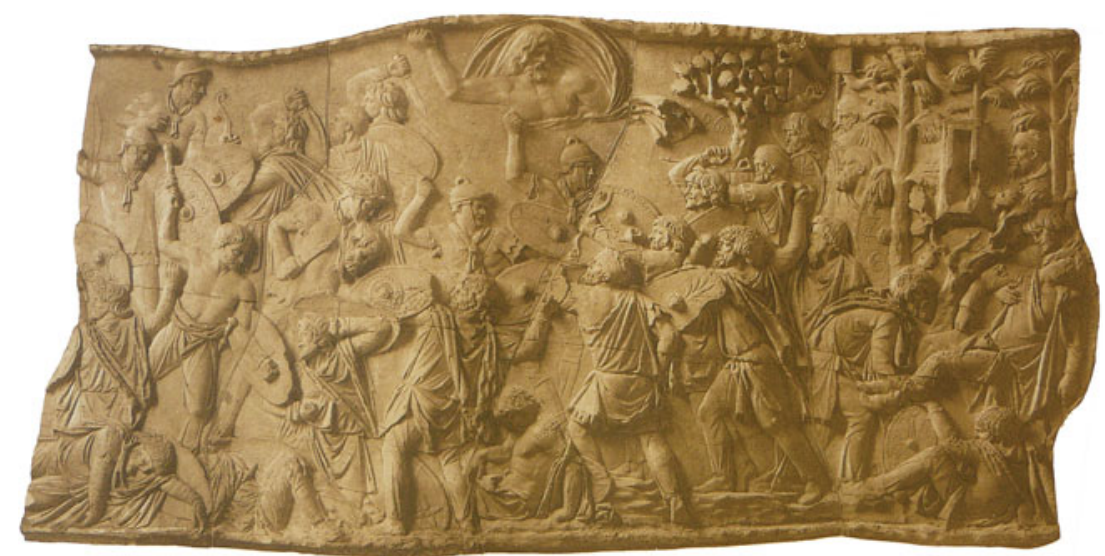

Fig. 3. Scene XXIV. Decebalus' head can be seen in the trees on the right, while Jupiter Tonans aims to hurl his thunderbolt from the left. The trees are identified as a D.18, A.5, A.5, D.16 (underneath the window) and a final A.5. Source: Cichorius 1896: plate XIX.

combining it with the direction of his throwing arm, we find that he appears to be aiming at the Dacian king (Settis et al. 1988: 146). Lepper and Frere (1988: 68) wondered whether this was the sole purpose of the deity's inclusion in the relief, or whether it was instead to indicate the thrust of the Roman forces, who advance into the forest under divine direction, or whether Jupiter Tonans' function is perhaps to indicate that the battle occurred during a thunderstorm (as Cichorius had earlier suggested), and to further imply the 'general support of Olympus' for the Roman cause. The ultimate conclusion, of course, is that the figure of Jupiter Tonans can have all the above functions, but the most obvious one to a viewer is the literal interpretation, that the god is aiming his wrath at the hiding Decebalus.

The trees themselves are mentioned in the commentary of Lepper and Frere (1988: 71), who identified them as reappearing 'to form the right-hand boundary of the scene', which underplays their significance in the scene. The trees at the close of scene XXIV do not function solely as a scene divider (the final resinous tree does this for the top half of the relief, but is obscured by the Dacians carrying their wounded comrade in the bottom half). Rather, they have multiple functions within the scene. The first function of the trees is that which was highlighted by Lepper and Frere, and is a structural one, closing a scene, and interrupting the narrative of the column. However, they directed their readers to the previous scene, XXIII, and the trees there. This is a deforestation scene, following a Roman advance through the forest (scene XXII), and the lack of ostentatious construction leads to the conclusion that the Roman soldiers are clearing a path for the advancing army (Coarelli, 2000: 64). Although Lepper and Frere (1988: 69) linked these trees to those which Decebalus reportedly dressed in Dacian armour at Tapae (Cass. Dio 67.10.23 ), it is easier to link these specific trees, and the episode as a whole, to the 
broader tradition of a war on the landscape. Nature is tamed by Roman forces in the scene leading up to the battle, and in the battle itself the trees are found only on the Dacian side of the scene, attempting to hide the king from the wrath of Jupiter Tonans.

When compared with the imperious figure of Trajan, both in scene XXIV with Decebalus and immediately behind him in scene XXV, the contrast between the rustic king and the urban emperor can be seen clearly. In scene XXIV, Trajan is dominant, giving the order to advance, as the heads of Dacians are shown to him. Meanwhile, Decebalus hides in the forest, distanced and uninvolved in the action of the scene, and identifiable at first viewing only by the direction of Jupiter's thunderbolt. This comparison is strengthened by the direct contrast between the figure of Decebalus in this scene, and Trajan, only two figures after him, in the following scene. In this appearance, Decebalus' depiction is a complete mirror image of that of the Roman emperor: he hides where Trajan leads, ${ }^{25}$ and, unlike Trajan's backdrop earlier in scene XXIV, of advisers and a stone wall, Decebalus' surroundings are rustic and arboreal. Thus, the opening depiction of Decebalus is not a flattering one on the relief, and the trees are integral in establishing the tone of this depiction.

Decebalus' final appearance on the relief is in the moment of his suicide underneath a tree identified as belonging to the quercus (oak) genus, in scene CXLV (Fig. 4). In this scene, the oversized figure of Decebalus is seen taking a knife to his throat at the foot of the tree as the Roman forces arrive. The tree is passed over by Lepper and Frere, and by Settis, the latter of whom only referred to it as a place identifier for Decebalus' prone form, although without an appreciation of the identifier's redundancy, given the gigantic proportions of Decebalus compared with the other figures on the column, and the direction of the other figures' gazes, focused on the fallen king.

Unlike the first appearance of Decebalus, with which this scene is directly comparable, the king is not hiding in the forest, but is clearly visible to the audience of the column. Here, the king's presence is the focal point, and his visibility is paramount. In addition to the oversized figure, and the concentrated gaze of all the surrounding figures and spears, the tree acts as a framing device for the king. In an extremely rare appearance on the relief, and contradicting the expected structure of the tree, there is a branch halfway up the trunk. This branch, which is short and leafy, shades Decebalus, framing him as an individual within the forest, and forcing the figure into a prone position. The tree, the trunk of which is behind the king, further isolates Decebalus, not from the Roman forces, but from his own sons, as Cichorius, followed by Lepper

25 The extent of Decebalus' concealment can be seen by the genera of trees which surround him: three resinous trees (all listed as A5 by Stoiculescu), and two deciduous (the first is catalogued by Stoiculescu as D18, the second (under Decebalus) is a D20). With particular regard to the shade of the resinous trees, ancient authors have a great deal to say on the shade cast by them, with particular reference to the pinus and the picea (Plin. HN 17.91; Hor. Carm. 2.3.9-11; Serv. Comm. Aen. 9.86; Sil. Pun. 1.83). 


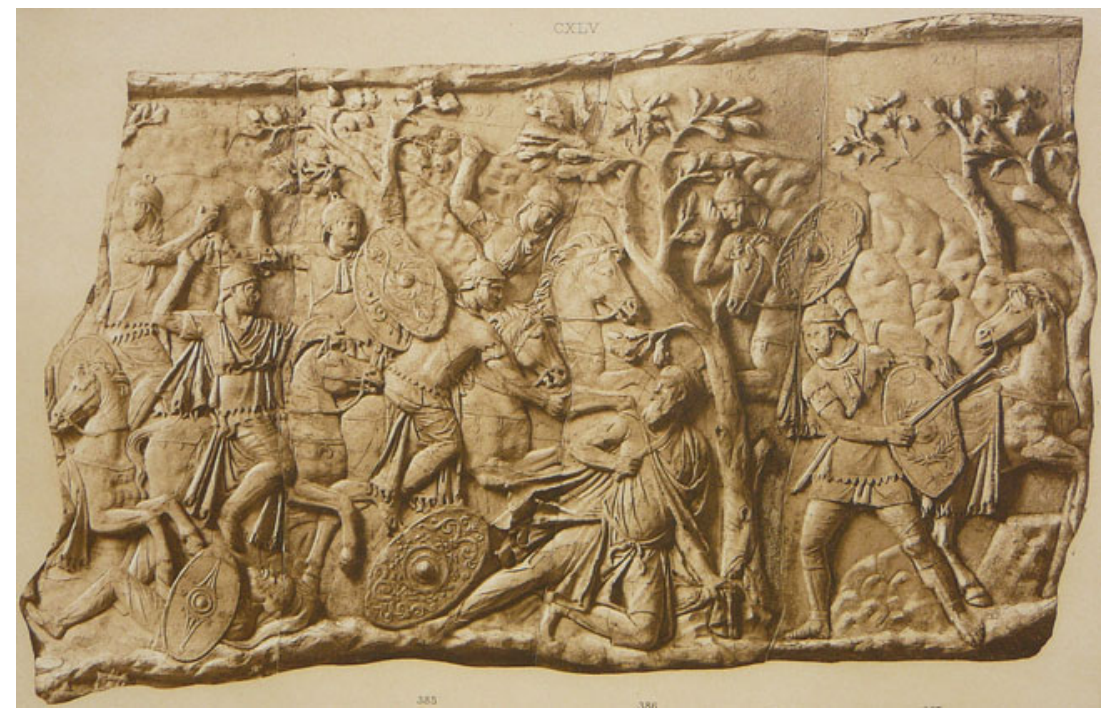

Fig. 4. Scene CXLV. The trees are identified as C.11, E.22 (under which can be seen Decebalus), C.13 and E.23. Source: Cichorius, 1896: plate CVI.

and Frere (1988: 177), identified the two figures. Here, the tree acts as an internal scene divider, providing compositional emphasis, similarly to the way that the rich drapes that surround Jupiter Tonans do in scene XXIV.

The choice of the oak tree can be construed as a continuation of Jupiter's ire, echoing the thunderbolt of scene XXIV, which is further down the same side of the column, on the well-attested northwest, or 'Victory', axis. The column could never be read as a continuous spiral, and if we are to assume that viewers would have been standing at a gallery, or unable to circle the column to read the continuous relief, they would have read the column as a vertical axis (Bianchi Bandinelli, 1978: 139; Settis et al. 1988: 202-3; Coarelli, 2000: 19).26 As a result, the viewer will have been able to compare the first appearance of Decebalus with the final one, directly above it, and would see corresponding symbolism. First, the thunderbolt of Jupiter Tonans isolates the figure of Decebalus, who is only watched by the deity. And at his death, the oak tree, sacred to Jupiter, again isolates the Dacian king from his sons, forcing him from the shadows of his first appearance, and thrusting him into the foreground at the moment of his death. At this, the climactic moment of the Dacian Wars, and of the column's relief, the landscape of Dacia, represented by

26 This particular vertical axis is perhaps the most significant on the column, containing the crossing of the Danube at the base, the first appearance of Decebalus, being targeted by Jupiter, the Victory appearing between two Dacian tropaea, and the suicide of Decebalus at the top of the column. In her analysis of Victoria's position on this axis, Kousser comments that the axis can be read as a synopsis for the campaign, from its origins at the Danube to its moment of closure (Kousser, 2008: 85). 
the tree most commonly associated with Dacia, betrays the Dacian king, and works for the Romans, thus paralleling the rivers and mountains in Pliny the Younger's writing. Thus, the scene not only shows the defeat of the Dacians, but also the subjugation of Dacia itself, and the Romans' war on the landscape is complete.

There are two other appearances of Decebalus on the relief in which trees play a part. First, Decebalus observes a battle from a forest, and is framed by trees, in scene CXXXV (Fig. 5). Lepper and Frere commented (1988: 173) that 'the tree at the junction of Casts 360 and 361 (and the rocks beside it) detach Decebalus from the thick of the fight', and added that 'a second tree firmly separates Decebalus and his bodyguard from the next scene'. Settis (Settis et al. 1988: 144) further drew attention to the isolation of the Dacian king, although he focused on the eyelines of the king's entourage, which are directed away from the king, focusing instead on the action. This is, for Settis, a passive scene, unlike an earlier, comparable scene (XCIII), in which Decebalus' entourage are focused on him. The trees function as the most obvious isolating tool here, and are combined with a low wall to separate Decebalus further from his surroundings. With a similar emphasis on framing to that in scene CXLV, the trees arch over the scene, containing Decebalus and his entourage as separate from the action, and only one forearm is allowed to intrude on Decebalus' contained entourage, thus connecting the two scenes, together with the gaze of the figures, who focus beyond the bounds of their frame, much like Decebalus' first appearance on the column. The trees have a dual purpose in this scene: on the one hand they act as a haven for Decebalus and his entourage, much like the trees do in Decebalus' first appearance, and distance him from the battle happening around him, to which he is only linked by eyeline and an intruding arm. This separation is not necessarily a positive one, and it is noticeable that there is no comparable appearance of Trajan, who is elevated from his people, but never separated from them. This is the second function of the trees within the scene, which focus attention on the Dacian king, elevating him and highlighting his importance, and his regality as the enemy forest king. In this aspect, perhaps, Decebalus is compared with Trajan, but the comparison ends with the elevation. The trees separate the Dacian king, highlighting both his isolation in the scene, and his rusticity.

The separation of Decebalus from his men by trees is again seen in his penultimate appearance on the relief, in scene CXXXIX (Fig. 6). Here, Decebalus holds council with his fellow pileati in a woodland setting after the looting of his treasure by the Roman forces. The trees in this scene are intermittent, two acting in a rough framing capacity, and a third, background tree, between the two, to the right of Decebalus. As in scenes XXXV, CXXXV and CXLV, this tree could be seen to be isolating Decebalus from his men, although it does so in so subtle a manner that it serves as an indication of the continued forest throughout the scene. The choice of tree as a framing device is consistent with the usage of other deciduous trees as framing devices elsewhere on the relief. The shaping of the tree, with overhanging branches rather than a 


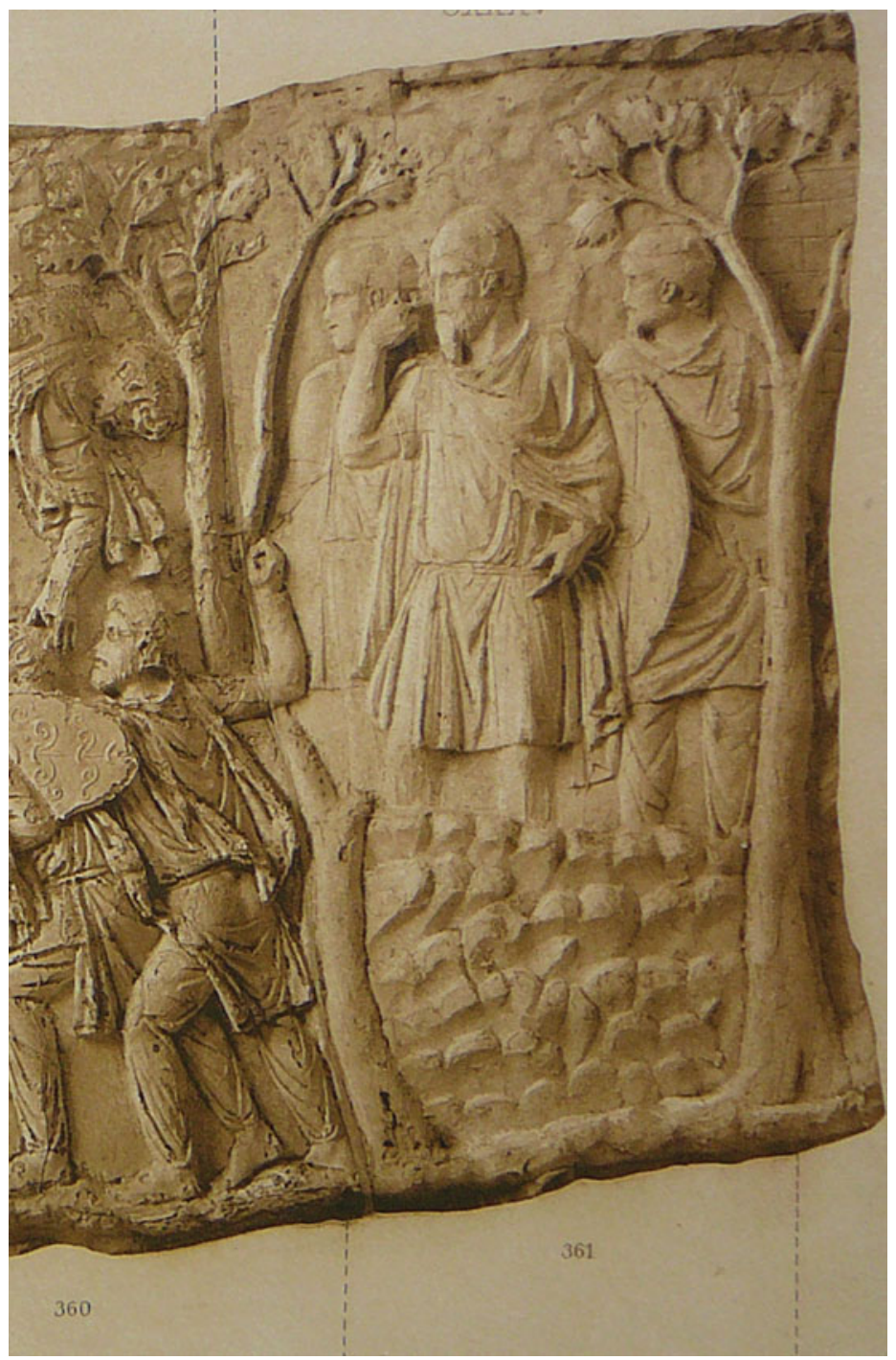

Fig. 5. Scene CXXXV. The trees are identified as E.26 and D.16. Source: Cichorius, 1896: plate XCIX.

single straight trunk, allows for the scene to be contained both at its edges and at the top of the scene. By containing Decebalus here with a background tree, as opposed to the foreground tree which isolates him from his troops in scene CXLV, the relief identifies him within the scene. This is directly comparable to Trajan's appearance in scene XXXVI, in which two background trees frame him as the key figure of the scene. Decebalus' appearance in the forest is similar to Trajan's appearances elsewhere on the relief, since this is the only scene in which a figure other than the emperor appears in an adlocutio stance. This is one of the most flattering depictions of Decebalus on the relief, since he begins to conform to the expected role of a statesman on the column, which is typified 


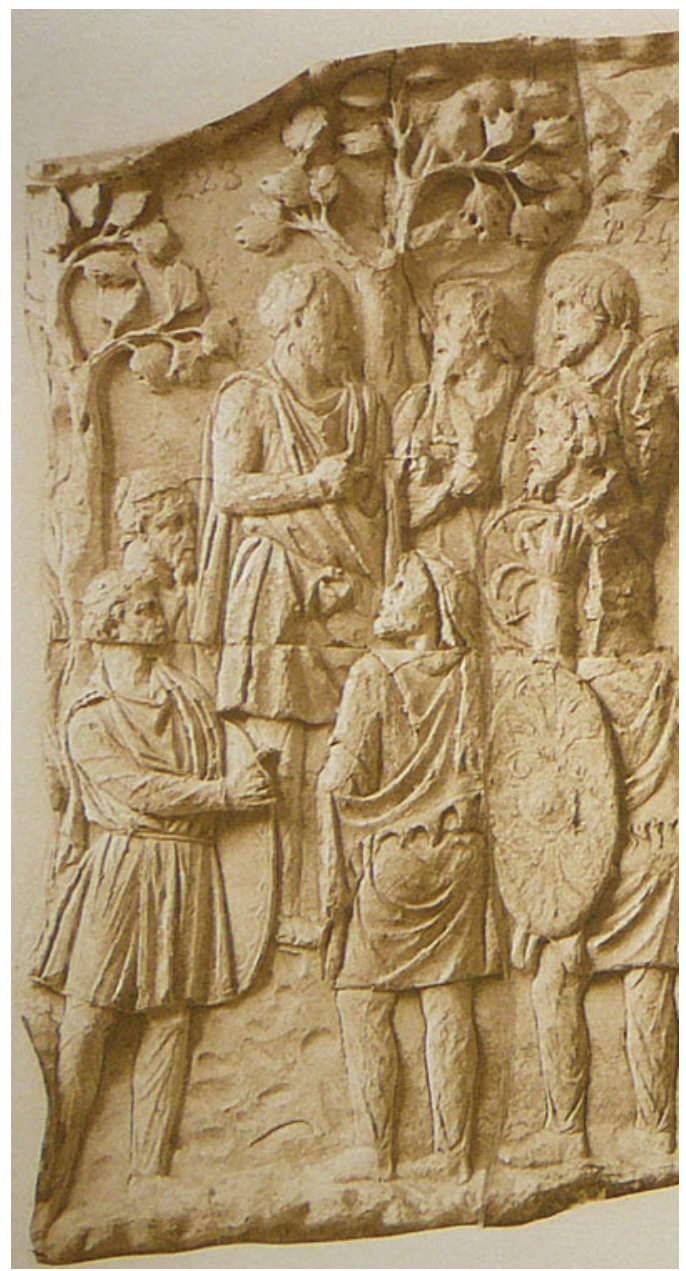

Fig. 6. Scene CXXXIX. The trees are all identified as D.21. Source: Cichorius, 1896: plate CII.

by Trajan's behaviour. As a result, the sculptor here is highlighting rather than isolating the figure of Decebalus, bringing him to the fore in a defining moment of the war, as the Dacian king organizes a retreat. It is not necessarily a good moment for the king to be highlighted, and all the elements of the Dacian defeat come to the fore in this scene: their king, in their native forest, orders their flight, abandoning their country to the advancing Romans, including the trees which will later separate the king from his men (scene CXLV).

Unlike Decebalus, Trajan is found in proximity to trees only a handful of times, and each with a similar purpose: to reiterate the 'war on landscape' tradition, and to frame parts of the action. In the first of three appearances, Trajan is seen leading auxiliary forces into a forest, where he receives a report from a group of scouts (scenes XXXVI-XXXVII). He is next seen receiving a Dacian 


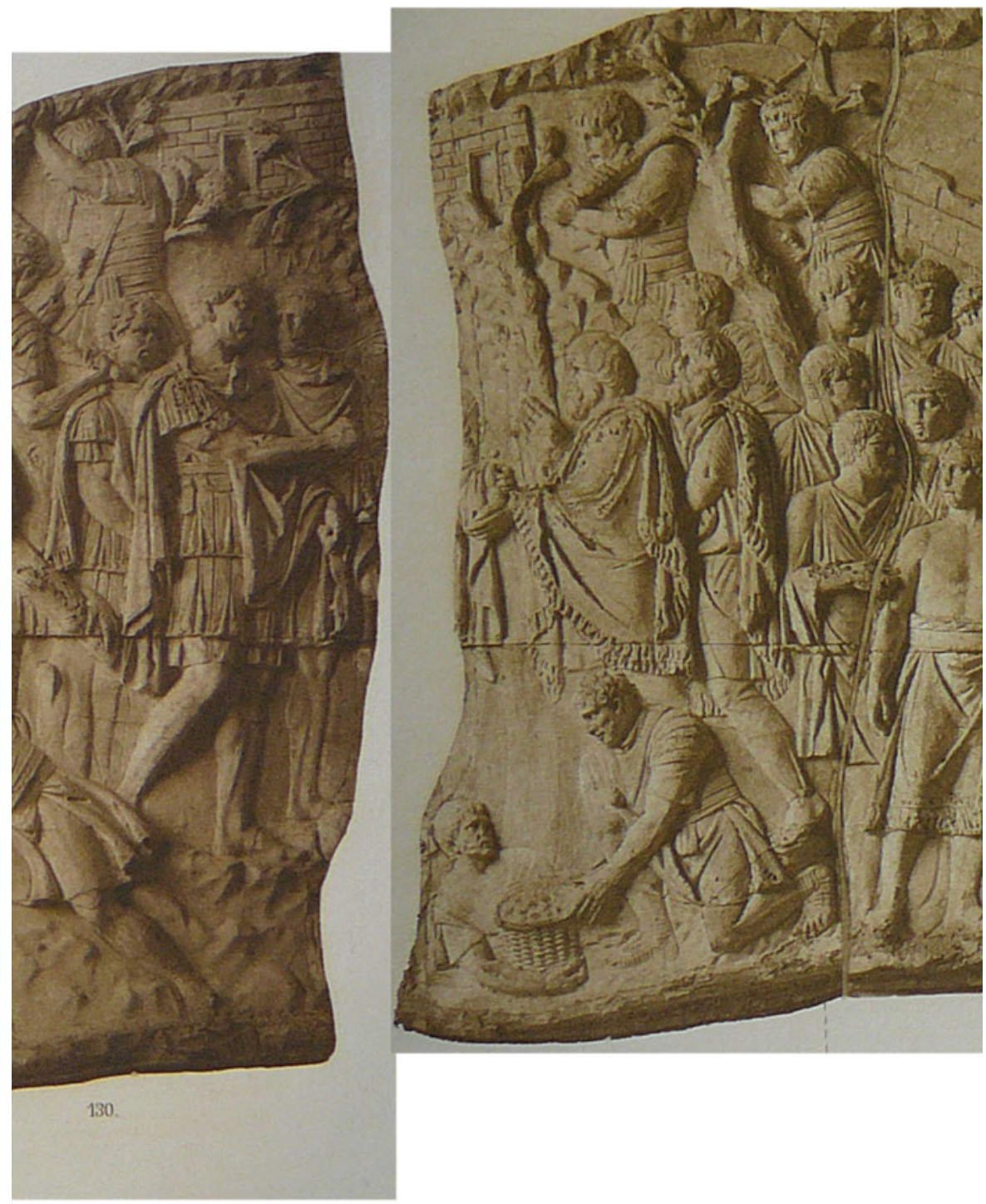

Fig. 7. Scene LII, showing Trajan greeting a Dacian embassy. The trees are both identified as E.22. Source: Cichorius, 1896: plates XXXVII; XXXVIII.

embassy, which emerges from the trees of a forest that is being cut down and tamed by the Romans (scene LII: Fig. 7). The final appearance of Trajan in the context of a forest is in scene LXVIII, in which a prisoner is brought in front of the emperor, again from the forest. Each of these scenes is one of two sides, of presentation to Trajan, either the scouts presenting a report of the Dacian territory to Trajan (scenes XXXVI-XXXVII), or the prisoner being presented in scene LXVIII. In these scenes, the trees additionally function in a framing 
context, dividing the two sides, and in the case of the battle, the two scenes. ${ }^{27}$ However, in the case of the Dacian embassy (scene LII: Fig. 7), the scene dynamic has shifted noticeably. Here, Trajan stands facing away from the deforestation behind him, as his forces tame the Dacian landscape, and he receives a Dacian envoy, who is seen extending his hands in greeting and supplication across the division of the tree, and the safe haven of the Dacian forest. The emotion of this scene is clear. What was once Dacian territory is now being controlled and manipulated by the Roman forces, and the Dacian embassy must now enter a foreign, newly urbanized landscape in order to negotiate with their Roman enemy. This is common throughout Trajan's arboreal appearances on the column, and in every instance the forest is associated with the opposing forces, and the urban sophistication of the emperor is contrasted with the rustic simplicity of the Dacians, epitomized by their almost exclusively arboreal king, who is eventually betrayed by the tree which fundamentally represents the land of Dacia.

\section{CONCLUSION}

Contemporary literature about the Dacian Wars, such as Pliny the Younger's Panegyricus, and his letter to Cannius Rufus, can suggest the important role that certain Romans ascribed to the landscape in times of war. In these texts, the mountains, seas and rivers are presented as active participants in Pliny's description of the war, which is often assumed to be hyperbolic as a result of the literary genre in which it appears. However, the frieze on Trajan's Column demonstrates the boundless nature of this hyperbole, unrestricted by generic boundaries. Nature plays an active role in the column's relief, and is crucial in communicating its message of Roman dominance and superiority over a foreign enemy and their land.

The trees of Dacia are prominent on the column's relief, and are carved in intricate detail, from the base of the relief to the very top. These trees conform with remarkable accuracy to the trees of Dacia, and one of the more common trees on the relief, the oak, may have been regarded as particularly Dacian, despite its widespread growth throughout Europe. This function of the trees as accurate representations of Dacia is one of the more prosaic uses of trees on the column, and is limited as a raison d'être for the presence of trees on the column's relief. In looking at Trajan's Column, however, we see the complexity of Rome's relationship with trees, and the trees on the relief work within a complex set of conflicting traditions, those of negative deforestation, and war on the landscape. These two traditions dominated ancient thinking with regard

27 The tree divider between the two sides of the battle is one which was devised by Cichorius, and could be reinterpreted as a division within the scene, splitting two halves of the same conflict. The lack of clarity to the scene division is further emphasized by the crossing of the barrier by each side. 
to the relationship between the Romans and their environment. The column's narrative focuses principally on the latter tradition. In the theme of 'war on the landscape', the trees function as diagnostic features of Dacia, and are a target for the Romans to subjugate, and as a vehicle for the message that the Roman army is exercising complete control over the Dacian territories on the column's relief, thus accounting for the large number of deforestation scenes on the relief and corresponding to the response of the landscape in Pliny's Panegyricus. Further to this message, the associations of environment are clear within the narrative of the column, as is most apparent in depictions of the two leaders, Decebalus and Trajan. In a comparison between the two figures, we can see that the Dacian leader is depicted primarily in arboreal settings, and the sculptors have used the trees to highlight his role in scenes, and to dictate his role in them, from being a back-room general, hiding from the battle in a forest, to being isolated from his men, abandoned by his own land, represented by the tree which presents his suicide to the Roman forces. Meanwhile, Trajan is distanced from trees, and is only ever seen advancing into them, never within the forest itself. He orchestrates deforestation scenes, and the taming of the Dacian landscape, even in the face of the Dacian embassy in scene LII. When the quantity and detail of the trees on the column are combined with the theme of the war on the landscape, expressed through the numerous deforestation scenes on the column and the distinction between an urban emperor and a forest king, a key purpose of the trees becomes clear: they serve to demonstrate that the war shown on the column is not just against the Dacians, but against the land of Dacia itself.

Address for correspondence:

Andrew Fox

B01 Humanities Building, University of Nottingham, University Park, Nottingham NG7 2RD

andrew.fox@nottingham.ac.uk

\section{REFERENCES}

Bianchi Bandinelli, R. (1978) Dall'Ellenismo al Medioevo. Rome, Editori Riuniti.

Boetticher, K. (1856) Der Baumkultus der Hellenen nach den gottesdienstlichen Gebräuchen und den überlieferten Bildwerken dargestellt. Berlin, Weidmann.

Brilliant, R. (1984) Visual Narratives: Storytelling in Etruscan and Roman Art. Ithaca (NY), Cornell University Press.

Carettoni, G. et al. (1960) La pianta marmorea di Roma antica. Rome, Ripartizione del commune di Roma.

Cichorius, C. (1896) Die Reliefs der Traianssäule, vol. 2. Berlin, Georg Reimer.

Coarelli, F. (2000) The Column of Trajan, trans. C. Rockwell. Rome, Colombo.

Coarelli, F. (2007) Rome and its Environs, trans. J. Clauss \& D. Harmon. Berkeley, University of California Press.

Conti, C. (2000) The restoration of Trajan's Column. In F. Coarelli (ed.), The Column of Trajan: 246-9. Rome, Colombo.

Coulston, J.C.N. (1990a) Three new books on Trajan's Column. Journal of Roman Archaeology 3: 290-309. 
Coulston, J.C.N. (1990b) The architecture and construction scenes on Trajan's Column. In M. Henig (ed.), Architecture and Architectural Sculpture in the Roman Empire, 39-50. Oxford, Oxford University Committee for Archaeology.

Coulston, J.C.N. (2003) Overcoming the barbarian: depictions of Rome's enemies in Trajanic monumental art. In L. De Blois (ed.), The Representation and Perception of Roman Imperial Power: 389-424. Amsterdam, J.C. Gieben.

Davies, P.J.E. (1997) The politics of perpetuation: Trajan's Column and the art of commemoration. American Journal of Archaeology 101: 41-65.

Dowden, K. (2000) European Paganism: The Realities of Cult from Antiquity to the Middle Ages. London, Routledge.

Dyson, J.T. (2001) King of the Wood: The Sacrificial Victor in Virgil's 'Aeneid'. Norman, University of Oklahoma Press.

Fabrizi, V. (2016) Space, vision and the friendly sea: Scipio's crossing to Africa in Livy's Book 29. In E. Baltrusch, H. Kopp and C. Wendt (eds), Seemacht, Seeherrschaft und die Antike: 279-90. Stuttgart, Franz Steiner.

Ferris, I. (2000) Enemies of Rome: Barbarians through Roman Eyes. Stroud, The History Press.

Gauer, W. (1977) Untersuchungen zur Trajanssäule. Berlin, Gebr. Mann.

Goldman, N.W. (1994) Roman footwear. In J.L. Sebesta and L. Bonfante (eds), The World of Roman Costume: 101-29. Madison, University of Wisconsin Press.

Houston, G.W. (1989) The state of the art: current work in the technology of Ancient Rome. The Classical Journal 85: 63-80.

Hughes, J.D. (2014) Environmental Problems of the Greeks and Romans: Ecology in the Ancient Mediterranean (second edition). Baltimore (MD), Johns Hopkins University Press.

Hunt, A. (2016) Reviving Roman Religion: Sacred Trees in the Roman World. Cambridge, Cambridge University Press.

Hutchinson, G.O. (2011) Politics and the sublime in the Panegyricus. In P. Roche (ed.), Pliny's Praise: The Panegyricus in the Roman World: 125-41. Cambridge, Cambridge University Press.

Kousser, R.M. (2008) Hellenistic and Roman Ideal Sculpture: The Allure of the Classical. Cambridge, Cambridge University Press.

Kuttner, A. (1999) Culture and history at Pompey's museum. Transactions of the American Philological Association 129: 343-73.

Leander-Touati, A.-M. (1987) The Great Trajanic Frieze: The Study of a Monument and the Mechanisms of Message Transmission in Roman Art. Lund University, Ph.D. thesis.

Lehmann-Hartleben, K. (1926) Die Trajanssäule. Ein römisches Kunstwerk zu Beginn der Spätantike. Berlin, De Gruyter.

Lepper, F. and Frere, S. (1988) Trajan's Column: A New Edition of the Cichorius Plates. Gloucester, Alan Sutton.

Lloyd, R. (1982) Three monumental gardens on the marble plan. American Journal of Archaeology 86: 91-100.

Malissard, A. (1982) Une nouvelle approche de la colonne Trajane. Aufsteig und Niedergang der römischen Welt 12: 579-606.

Manolaraki, E. (2008) Political and rhetorical seascapes in Pliny's Panegyricus. Classical Philology 103: 374-94.

Meiggs, R. (1982) Trees and Timber in the Ancient Mediterranean World. Oxford, Clarendon Press.

Östenberg, I. (2009) Staging the World: Spoils, Captives, and Representations in the Roman Triumphal Procession. Oxford, Oxford University Press.

Packer, J. (1997) Trajan's Forum: A Study of the Monuments. Berkeley, University of California Press.

Packer, J., Sarring, K.L. and Sheldon, R.M. (1983) A new excavation in Trajan's Forum. American Journal of Archaeology 87: 165-72. 
Pogorzelski, R. (2012) Die Traianssäule in Rom. Dokumentation eines Krieges in Farbe. Mainz, Nünnerich-Asmus.

Radice, B. (1968) Pliny and the Panegyricus. Greece and Rome 15: 166-72.

Roche, P. (ed.) (2011) Pliny's Praise: The Panegyricus in the Roman World. Cambridge, Cambridge University Press.

Rossi, L. (1968) The representation on Trajan's Column of Trajan's rock-cut road in Upper Moesia: the emperor's road to glory. The Antiquaries Journal 9: 41-6.

Rotili, M. (1972) L'Arco di Traiano a Benevento. Rome, Istituto poligrafico dello Stato.

Russell, A. (2016) The Politics of Public Space in Republican Rome. Cambridge, Cambridge University Press.

Schama, S. (1995) Landscape and Memory. New York, Alfred A. Knopf.

Settis, S., La Regina, A., Agosti, G. and Farinella, V. (1988) La Colonna Traiana. Turin, Giulio Einaudi.

Stackelberg, K.T. von (2009) The Roman Garden: Space, Sense and Society. New York, Routledge. Stoiculescu, C.D. (1985) Trajan's Column documentary value from a forestry viewpoint (Part 1). Trans. A. Liiceanu, rev. E. Bărbulescu. Dacia 29: 81-98.

Syme, R. (1958) Tacitus. Oxford, Clarendon Press.

Thill, E.W. (2010) Civilisation under construction: depictions of architecture on Trajan's Column. American Journal of Archaeology 114: 27-43.

Thomas, R.F. (1988) Tree violation and ambivalence in Virgil. Transactions of the American Philological Association 118: 261-73.

Totelin, L. (2012) Botanizing rulers and their herbal subjects: plants and political power in Greek and Roman literature. Phoenix 66: 122-44.

Tuck, S.L. (2015) A History of Roman Art. Oxford, Blackwell.

Wootton, W. et al. (2013) Art of Making. http://www.artofmaking.ac.uk/ (accessed on 15 November 2016).

Wootton, W. and Russell, B. (2013) Carving imperial reliefs at Rome (version 1.0). The Art of Making in Antiquity: Stoneworking in the Roman World. www.artofmaking.ac.uk/content/essays/4carving-imperial-reliefs-at-rome-w-wootton-b-russell/ (accessed on 15 November 2016). 